\title{
Surfaces
}

\section{HUMANISTIC DISCOURSE AND THE OTHERS}

\section{J. Hillis Miller}

Volume 4, 1994

CONFÉRENCE INTERNATIONALE SUR LE DISCOURS HUMANISTE

(PREMIÈRE RENCONTRE, 3-8 AVRIL, 1994)

INTERNATIONAL CONFERENCE ON HUMANISTIC DISCOURSE (FIRST

MEETING, APRIL 3-8, 1994)

URI : https://id.erudit.org/iderudit/1064968ar

DOI : https://doi.org/10.7202/1064968ar

Aller au sommaire du numéro

Éditeur(s)

Les Presses de l’Université de Montréal

ISSN

1188-2492 (imprimé)

1200-5320 (numérique)

Découvrir la revue

Citer cet article

Hillis Miller, J. (1994). HUMANISTIC DISCOURSE AND THE OTHERS. Surfaces, 4. https://doi.org/10.7202/1064968ar
Résumé de l'article

Considérant cruciale à toute discussion portant sur la culture et le discours humaniste une réflexion approfondie sur la question de l'altérité, l'auteur développe l'idée de l'Autre conçu comme non-concept en s'inspirant des diverses conceptions de l'altérité élaborées, entre autres, par Lévinas, Lacan, Derrida, et de Man. En conclusion, il commente le débat entourant le statut institutionnel des départements d'études anglaises aux État-Unis. 


\title{
HUMANISTIC DISCOURSE AND THE OTHERS
}

\author{
J. Hillis Miller
}

\begin{abstract}
This essay focuses on the question of otherness as crucial for discussions of culture and humanistic discourse. In developing an idea of the non-concept of the Other, it summarizes articulations of otherness in Lévinas, Lacan, Derrida, and de Man, among others. In conclusion, it addresses the institutional situation of English departments in the United States.
\end{abstract}

\section{RÉSUMÉ}

Considérant cruciale à toute discussion portant sur la culture et le discours humaniste une réflexion approfondie sur la question de l'altérité, l'auteur développe l'idée de l'Autre conçu comme non-concept en s'inspirant des diverses conceptions de l'altérité élaborées, entre autres, par Lévinas, Lacan, Derrida, et de Man. En conclusion, il commente le débat entourant le statut institutionnel des départements d'études anglaises aux Etat-Unis.

The phrase "humanistic discourse" sounds innocently descriptive. Nevertheless, each word begs a lot of questions. No doubt that is why the word is put in scare quotes in the description of our project. Though "humanistic discourse" can be taken simply to designate the languages of the humanities as opposed to those of the social sciences or the natural sciences, nevertheless the word "humanistic" implies that all men and women of all nations at all times share a common essence. This essence distinguishes them from animals or inanimate objects. They are all human beings. This paper is an attempt to reflect on what follows if there is no such common essence making "us" all human beings sharing the earth together. 
Suppose there were no "us" that might give a definable unity and meaning to the word "humanistic"?

The word "discourse," though it too seems neutral enough, is equally problematic. Focusing on it tends to give primacy to language as constitutive of culture. Our increasingly visual culture may put that primacy in question. For better or worse fewer and fewer people have their sense of themselves and their sense of belonging to a community determined exclusively or even predominantly by language. Television, film, video, the pictures in newspapers and magazines, popular music, often in video form -- these more and more make "us" in the West, and in the rest of the world too, what we are. Reading novels or poems has less and less importance anywhere. Fewer and fewer cultures around the world have not been decisively affected by these new media. So some ponderous phrase like "humanistic sign systems" might have been better, even if "we" could have swallowed "humanistic."

"Discourse," moreover, transforms the language of poetry, novels, other media, and the criticism of them into something that can be held at arm's length and analyzed, made the object of a cognitive investigation, as in "discourse analysis." It may be that the most important feature of what we are calling in this conference "humanistic discourse" -- let us say in shorthand both literature or philosophy and language about them, is not that it gives knowledge or that it can be known but that it does something. This something that is done we do not perhaps so much know as bring about by reading. If reading, writing, or talking in "humanistic discourse" is an act of doing rather than knowing, it follows that "we" should take responsibility for this doing, as we must for any act, even though we may not clearly know what we are doing.

What would it mean for "'humanistic' 'discourse'" if humanity were radically heterogeneous, not totalizable, other to itself? It would mean, for one thing, that the "space between" is not the gap between one culture and another or between one discourse within a single culture and another but inside, within, fissuring any enitity that may be singled out as having a putative unity, including each single "self" with a cultural identity, each cultural work, linguistic or otherwise, produced by the self or by a community of them, each community, ethnic group, or nation, even humanity itself taken as a vast heteronomous non-whole. The word "other" in my formulation "other to itself" is a clue to be followed.

The word or the concept of "the other" is used in many different and by no means compatible ways in current humanistic discourse. Just what are those ways? They are easiest to think of as personified in a series of well-known names. These are names to conjure with in current theory and criticism, personifications of positions that exceed any one person and that do not themselves have the unity we associate with personality of personhood. I give these names pell-mell, in no particular order, neither hierarchical, nor logical, nor even chronological.

For Emmanuel Lévinas "the other" is an absolute trancendence, "beyond being," who leaves traces of itself or himself in the face of the other person. Lévinas says traces, not signs. A sign presupposes the existence and 
availability of its referent. A trace is a catachresis (though Lévinas does not use this word) for something or someone I can never confront directly. He or it belongs to "a past absolutely bygone" (357).

For Jacques Lacan, in a celebrated formulation, "the unconscious is the discourse of the other." This presence of the other within my depths, out of my sight, sets up those triangular Lacanian relations in which the letter circulates among three persons. Lacan has expressed this circulation as the law of the three ostriches: one with its head buried in the sand, the second thinking he or she is therefore invulnerable, while the third calmly plucks the tailfeathers of the second. This law is investigated in Lacan's essay on Poe's "The Purloined Letter." That story is a letter that has been passed around from critic to critic in contemporary theory: from Poe to Baudelaire to Lacan to Jacques Derrida to Barbara Johnson to others, in a ceaseless dissemination. What is most problematic about Lacan's writing might be economically phrased by asking whether the "other" is really "other" for Lacan, or whether, for him, in Derrida's phrase, the letter always reaches its destination, that is, can be brought out in the open, pinned down to a definite meaning, for all to read, or at least for its destined recipient to read. When this happens the other is assimilated, becomes the same, or returns to the same.

For Jacques Derrida, on the other hand, as he says, the letter never reaches its destination, even though, like a postcard, it is exposed where all can read it. The letter is condemned to wander interminably not so much in its plurisignificance as in its aporetic indeterminacy of meaning and addressee. For Derrida, as he says, "Tout autre est tout autre." The notion of otherness has fundamental importance from one end of Derrida's work to the other, even when it is given other names, or glimpsed in different ways, for example in the reference of "la différance" to a past that never occurred, or in the exploration in "Fors" of what it means to speak of an event that took place without ever having taken place and that has brought it about that the Wolfman is haunted by a dead-alive body in a crypt in his unconscious. It would be a long trek to track the Protean other through all the diversity of Derrida's work. Three recent essays confront the question of the other directly: the interview with Jean-Luc Nancy, the title essay in Psyché: Inventions de l'autre, and Derrida's book on death, Apories. In the latter Derrida patiently demonstrates that Heidegger's thought about death in its relation to Dasein is undermined by an aporia. If the otherness of death is wholly other it cannot be used as a distinguishing feature of Dasein. If death is the possibility of an impossibility, then it is impossible to say anything more about it than that. Even to say that is too much, since as an aporia it is an impasse in speech and thought, marking all the way in thought that has been traversed to get to it with the sign not of a "Holzweg" but of a "Dead End."

Richard Kearney asked Derrida in an interview in 1981: "What then of the question of language as reference? Can language as mutation or monstrosity refer to anything other than itself?" To this Derrida answered:

It is totally false to suggest that deconstruction is a suspension of reference. Deconstruction is always deeply concerned with the 'other' of language. I 
never cease to be surprised by critics who see my work as a declaration that there is nothing beyond language, that we are imprisoned in language; it is, in fact, saying the opposite. The critique of logocentrisim is above all else the search for the 'other' and the 'other of language. '... Certainly deconstruction tries to show that the question of reference is much more complex and problematic than traditional theories supposed. It even asks whether our term 'reference' is entirely adquate for designating the 'other.' The other, which is beyond language and which summons language, is perhaps not a 'referent' in the normal sense which linguists have attached to this term. But to distance oneself thus from the habitual structure of reference, to challenge or complicate our common assumptions about it, does not amount to saying that there is nothing beyond language.... I totally refuse the label of nihilism which has been ascribed to me and my American colleagues. Deconstruction is not an enclosure in nothingness, but an openness towards the other.[1]

The book by Nicholas Abraham and Maria Torok on the Wolfman is the occasion of Derrida's inventive commentary in "Fors." For Abraham and Torok the other is characteristically associated with ghosts, melancholy, and haunting. In another essay they propose the extraordinarily provocative possibility that Hamlet is haunted not by his father's ghost, but by his dead father's unconscious. The latter goes on living as a cryptic inhabitant, neither dead nor alive, in Hamlet's own unconscious and causes much perturbation in his conscious thoughts and feelings. Each of us, it may be, is haunted by the unconscious of the other.

For Frantz Fanon, Edward Said, and innumerable other cultivators of the field of cultural studies today, the term "other" names the racial, class, gendered, or national other. This cultural other is necessarily posited as the ground for the dominance of the hegemonic culture. This other that I posit in order to assert my own superiority is always a caricature or parody, shot through with ideological lies, just as is the sense of myself or of my nation, culture, or society. Nevertheless, this ideological image of the otherness of the other has great power. It is used to justify the most inhuman acts of cruelty, ethnic cleansing in Bosnia, for example, or the horrors of the Shoah.

Jean-François Lyotard's term "differend" names an irreducible difference between one person or group and another. As opposed to Jürgen Habermas, for whom dialogue has as its horizon a reconciling consensus, Lyotard presupposes a personal or social heterogeneity that can never be negotiated or talked out of existence. For Lyotard the social other, for example the racial, class, gender, or political other, is truly other. My values cannot by any means be reconciled with his or her values, nor subsumed at some higher level that will encompass them both. Only a democracy based on dissensus and on some idea of radical heterogenity in different persons and groups within a single polity could recognize and protect this radical otherness. Maurice Blanchot and Jean-Luc Nancy have tried to imagine what that "unworked" community might be like. William Readings in his brilliant diagnosis of the university and Diane Elam in an admirable book on feminism and deconstruction, Ms en abîme, have explored in different areas what a community of dissensus might be like. 
The "dialogical" in Mikhail Bakhtin's thought at first perhaps appears to be a confrontation through conversation's give and take of one person with another. But the term names an incongruity within language that can never be smoothed out in some monological discourse. Bakhtin gives this the name "heteroglossia." Just as Bakhtin appears to have been not just one person, Bakhtin, but at the same time also Voloshinov and Medvedev, or perhaps after all three different persons, so a dialogic discourse or a discourse of heteroglossia has two or more "logoi," two or more irreconcilable centers of emission and control of meaning. An extraordinary passage in the essay "Discourse in Life and Discourse in Art (Concerning Sociological Poetics)" [2] suggests that dialogue is actually a triadic relation in which the motivating pole is the muteness and inhuman alienation of a material other.

Paul de Man does not seem to have much patience with portentous terms like "the other" or "others." His radical concept of irony, however, presupposes the encounter with an otherness within language that involves a permanent suspension of meaning. In de Man's last essays this otherness is given the strange quasi-Marxist name "materiality." Examples are phrases in his work that are by no means easy to understand about "the materiality of language" or "the materiality of history." "Materiality," in de Man's last essays, does not name the solid substance of physical materiality, open to the senses, namable and manipulable at our will. It names a radical alterity that is not phenomenal, that is not the object of a representable intuition, that cannot be confronted or referentially, literally named. Other displaced names for this de Manian other are "death" or "the impossibility of reading." This material other is the unmeaning and imperceptible base of all meaning, something not a part of what de Man calls "phenomenality." It vitiates and undermines clear meaning, as the contingency of puns makes language escape the control of him or her who uses it. An inadvertent pun (and language is full of inadvertent puns) makes the user say something different from what he or she intended to say. This something may nevertheless have performative effects in the real world, since it is only the effective materiality of language, beyond perspicuous meaning, that can be a historical event. De Man's radical revision of speech act theory detaches language, in particular the machine-like operations of grammar and the aporetic operation of tropes, from the control of the consciously willing "I." Language acts on its own to posit effective performatives. These enter the human world and make history through just those features of language that escape control and that de Man calls the "materiality" of language.

In all these different notions of otherness, a single problematic may be observed. On the one hand, the other is seen as part of a dialectical dyad either allowing for an Aufhebung or presupposing some "one" of which the two are derivatives. Such an alterity does not lead to aporias. If the other is really another form of the same much can be said, done, and thought. Powerful machines of thinking, saying, and doing are not impeded in their working. There is possibility of understanding and reconcilation. The two sides can talk, perhaps reach a consensus. The concept of multiculturalism, for example, often, though by no means always, presupposes a notion of culture that is common to all of the cultures juxtaposed in rainbow bands. However strange the other culture is, however different the minority culture 
within the hegemonic culture, it is still a culture. The concept of culture is a universal making possible a horizon of reconciliation or a respectful coexistence that the terms pluralism and "multiculturalism" name. This universalism means I can assume I am able to understand the alien culture, to put myself within it, to negotiate with it, in one way or another to assimilate it, to absorb it within sameness. I do not need to be a native American in order to understand and teach Native American literature and culture, just as I do not need to be an English man or woman to teach English literature. The entire institutionalization of the humanities in the United States (and in many other countries too) depends on this assumption. It is the basic presupposition, for example, of comparative literature as a discipline. It is not clear that the new programs in cultural studies or in "multiculturalism" consistently put that presupposition in question.

On the other hand, the other may be entirely other, that "tout autre" Derrida names. If that is the case then no negotiation or reconciliation is possible, only some speech act inventing, inaugurating, or instituting a fiction of the other. This alternative possibility, it may be, is intertwined, necessarily, with the first. If the other is the wholly other, that does not mean there is nothing there. The non-concept of the wholly other is as far as can be from any nihilism. I call it a "non-concept" because a concept forms part of a system of thought open to logical or dialectical synthesis, whereas the "wholly others" cannot be assimilated into any such system. The evidence that there is something there is the way the wholly others perturb every speech-actinstituted fiction, for example the fiction of personal, group, or national identity. They divide such unities within themselves, make them nontotalizable.

A parallel, though it is only a figurative one, a juxtaposition of incommensurables, may be drawn between the wholly others and those black holes astronomers hypothesize. A black hole does not, strictly speaking exist, if existence depends on being observable and measurable. That is why astronomers are so careful to remind us that no black hole has ever been observed. Black holes remain an unproved and perhaps unprovable hypothesis that explains certain observed celestial phenomena. Nevertheless, though it cannot be verified directly, a black hole may be inferred from matter's violent perturbation in its vicinity. Like black holes, the wholly others never manifest themselves directly, but give evidence of themselves in a variety of perturbations that can be registered.

Perhaps my own inner self, my conscience, presumed ground of my decisions and commitments, all the speech acts I enunciate, may be "encountered" (though it is not really an encounter) as wholly other. The wholly other, on the other hand, might be an incomprehensible and unknowable otherness glimpsed when I come face to face with another person, perhaps, though by no means necessarily, a person of the "other sex" or of a different sexual orientation. Perhaps the wholly other, on the contrary, is a power transcending cultural and personal difference, for example the inscrutability of Apollo and the other divinities in Oedipus the King or the unassimilable irrational in Aristotle's Poetics and Rhetoric. Such others come, as they say, "from beyond the world." Death, finally (what could be more final than death?), may be wrestled with as something wholly other, 
as in Henry James's The Wings of the Dove and Wallace Stevens's "The Owl in the Sarcophagus." Death as other by no means necessarily presupposes the existence of some transcendence, the gods or God, nor does it presume some heaven or hell, some other place to which we go when we are dead. Death leaves those questions pertmanently open, since death is that bourne from which no traveler returns. Death, my death, the death that most matters to me and that I would most like to know, cannot be experienced. Death is not an object of any "I"'s experience.

Perhaps the wholly other may be a racial, national, class, or gender other that is truly other and may not be comprehended by analogy with my own knowledge of myself and therefore negotiated with. Today's so-called "cultural studies"studies," like the discipline of anthropology, often, though certainly not always, presuppose that the cultural other can be understood and accommodated in some coalition subsumed under a common concept of culture. Suppose they were wrong about that? What would follow? Could there be a cultural studies of the wholly others? The critic treads on dangerous ground here, since this assumption about the wholly others may be an ideological presupposition excusing much violence and injustice. The human instinct when confronted with an inassimilable other is to obliterate it, as the Europeans did their best to obliterate the Native Americans. Could there be a cultural studies of the wholly others that would avoid this? This would generate a "humanistic discourse" different from any kind that presupposes transparency and reconciliation as a horizon or goal.

I shall now briefly consider the implications of this non-concept of the wholly others for one specific form of humanistic discourse: literature and academic language about literature in the United States. I shall think especially of Departments of English in the United States. This is of course only one small segment of humanistic discourse, even in the United States. I shall say nothing about journalistic discourse about the humanities or what elected politicians or foundation officials say about the humanities. There are spaces between and within each of these forms, though they also overlap. Much journalistic discourse about the humanities, for example, is written by people who hold academic positions. Since I shall put in question the synecdochic relationship that might allow me to assert that academic humanistic discourse in the United States can stand for humanistic discourse generally in the United States or abroad, I cannot claim to be speaking of more than one segment of humanistic discourse.

What is the present state of academic humanities discourse? A "crisis in representation," as Brook Thomas calls it, exists in our writing, teaching, and curricular design in departments of the national literatures and in comparative literature. In various ways most teachers in American colleges and universities used to believe in the validity of a part for whole or synecdochal relationship in literary study. A good literary work was presumed to be an organic whole, so the study of a part could be a means of understanding or teaching the whole. Teachers could use with a clear conscience the technique of detailed study of an abstract so brilliantly exploited, for example, in Eric Auerbach's Mimesis. The whole work, carefully chosen and explicated on the assumption that each part of it mirrored the whole, could then be used as a way of understanding what was 
in one way or another a homogeneous circumambient culture. One citation from Virginia Woolf's To the Lighthouse could represent, for Auerbach, the whole modernist practice of realistic representation. It was possible to claim, without seeing the claim as problematic, that study of Moby Dick would give readers a full understanding of mid-nineteenth-century American culture. Of course such claims were not always made quite so blatantly, but some version of such an assumption operated widely as an unquestioned ideolo- geme (but an ideological element is by definition unquestioned). The ideologeme may have been all the more powerful for being an unspoken assumption guiding the choice of the canon and the devising of curricula.

Few people have any longer an unshaken confidence in this paradigm, even those who most stridently assert it. We recognize, for example, that the United States is a multicultural and multilingual nation. A given work or canon represents only one part of a complex non-unifiable whole. To choose to teach Moby Dick rather than Uncle Tom's Cabin or even to choose to teach both of them together is not the result of a recognition that they are in some way objectively representative. It is the result of a motivated and unjustifiable choice. Nor can there any longer be a recourse to some standard of intrinsic superiority allowing us to say that Moby Dick is a better work than Uncle Tom's Cabin, since that standard too is the result of ideological bias. This loss of confidence in the possibility of justifying a syllabus on the basis of its objectively verifiable representative status is almost as much of a disaster for those trained in the old ways of teaching literature as would be a loss of confidence in the power of our elected representatives to stand for us in a representative democracy.

The crisis in representation in the humanities leads to enormous problems in establishing curricula, in practical work in teaching and writing about literature, in making decisions about appointments and programs. One reason, for example, that so much time is spent in theoretical speculation these days is that we have no consensus about just how we ought to proceed. Everyone feels he or she has to reinvent the whole institution of teaching literature in the university from the ground (or lack of ground) up. Bernard Bergonzi has written a polemical book about this change as it effects the discipline of English literature. The title of his book tells what he feels about these changes: Exploding English.

This crisis in representation for literature departments accompanies a larger crisis of representation for the university as a whole, in particular for the humanities as an element in a new kind of university in a different world of global economy and global communication. The old American paradigm for the research university was borrowed from the Humboldtian model of the University of Berlin. This was widely influential in the United States, for example, in the founding of The Johns Hopkins University in 1876. The professionalization of the disciplines of English and other modern European literatures began at Hopkins with the establishing of the Modern Language Association in 1883. Partly under the influence of Matthew Arnold, the study of one national literature, namely English literature, replaced in England and America the role given to philosophy in the original Humboldtian university. This original role for philosophy is enshrined still in the fact that we are all doctors of philosophy, whatever our discipline. The presumption 
was that the university's function was to serve a single unified nation-state by preserving and passing on its values and ideals. English Departments played a central role in fulfilling that function.

The concept of the nation-state on which such a definition of the English Department's mission was based has eroded in recent years. It has been replaced both by an internationalization or globalization of university research and by a recognition, in the United States, that our nation is multicultural, heterogeneous, diverse. For many people the old mission of the university no longer has persuasive force. We have not yet, however, invented a new paradigm for the nature and function of the university. The loss of this special role for the study of English literature puts English departments especially under stress in the new post-national, post-modern university. Those of us who are Professors of English have been deprived of our traditional role as preservers and transmitters of the unified values of a homogeneous nation-state. There was always something of an anomaly in basing the values of the United States on the study of English literature, that is, on the study of the literature of a foreign country where they happen to speak a version of our own language. It takes only a moment's thought to realize how different it is for a British citizen, of whatever class, gender, or race, to read Shakespeare, Milton, or Dickens, from what it is for an American to read them. They do not belong to us or express our national values or even the values of our hegemonic class in the same ways. Nevertheless, English literature was still the basis of a literary education in the United States when I got my undergraduate and graduate degrees in English literature not all that many decades ago. It is still to a considerable degree the case, for example at the University of California at Irvine, where there are between six and seven hundred English majors. My graduate English qualifying examination stopped with Thomas Hardy and included no American literature at all, much less any theory. But replacement of English literature with the study of an American literature seen as the expression of an integrated set of values to which all good citizens should adhere is no longer for most people a valid alternative to studying exclusively English literature.

What alternative would be best? William Readings of the University of Montréal has done brilliant work in thinking through the problems of what he calls the "postmodern university." A major theoretical and practical challenge confronts departments of English now to redefine their role in the new kind of university and the new kind of non-unified national culture. If we do not find this new role we shall end up serving a purely ancillary function as teachers of communication skills for a predominantly technological university.

I agree not only with Readings, but also with Derrida, Lyotard, Diane Elam, Gerald Graff, and many others who have in different ways called for the creation of a university of dissensus, that is, one in which the impossibility of reconciling differences by dialogue or by increased knowledge would be openly recognized and institutionalized. A newly conceived English department might have an important role in such a university, but not as the promulgator of a single canon or a single national ideology. Thomas Jefferson said the United States ought to have another revolution every 
twenty years. One might imagine a university that remains in a state of permanent revolution, that is, one in which teaching and research would be defined not as the preservation and augmentation of what is already known but as the invention and discovery of the new, in response to a demand made on us by the other of what we already have. Thinking out what that might mean in practical terms for teaching, research, and curriculum planning is a major task for humanists today.

\section{J. Hillis Miller}

Department of English and Comparative Literature

University of California

Irvine, CA 92717

714-856-7445

e-mail: jhmiller@uci.edu

\section{Surface Page d'Acceuil/Home Page}

[1]Jacques Derrida, "Deconstruction and the Other," in Richard Kearney, Dialogues with contemporary Continental thinkers: The phenomenological heritage (Manchester: Manchester University Press, 1984): 123-124.

[2]In V. N. Volosinov, Freudianism: A Marxist Critique, trans. I. R. Titunik (New York: Academic Press, 1976): 93-116, espec. 98-106. See also Thomas Cohen's admirable discussion of this passage, "'Well!': Voloshinov's DoubleTalk," SubStance 21;2 (1992): 91-101. 